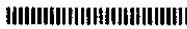

觛文

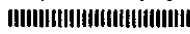

\title{
光相関法を用いた糸速度の計測
}

\author{
豊田中央研究所 木 佐 貫 義 勝 \\ 吉田 一 徳 (会員)
}

\section{Yarn Velocity Measurement Using Optical Correlation Method}

\author{
Yoshikatu kisanuki, Kazunori Yoshida \\ Toyota Central R\&D. Labs., Inc., \\ Nagakute, Aichi-gun, Aichi
}

\begin{abstract}
A high performance yarn speedometer adopting optical correlation method has been developed to contribute to efficient improvement of looms.

Among some velocity measuring methods, optical correlation method is the most suitable for a yarn intense speedometer because of its high accuracy and simple equipment composition.

Optical characteristics of spinning yarn and filament yarn were investigated for the development.

The investigation of frequency characteristics revealed that transmitted light intense signals for both the yarns were roughly random, which indicates optical correlation method was suitable for velocity measurement.

Measuring accuracy of a trial manufacture yarn speedometer was checked by measuring the velocity of the yarn which moved at a constant velocity.

The influence of the structural factors of the trial yarn speedometer on the accuracy was also examined.

Based on the above result, the trial yarn speedometer was adjusted optimally and the yarn velocity near the main nozzle of air jet loom was measured.

The measuring accuracy of the adjusted speedometer was found comparable to that of laser Doppler
\end{abstract} velocimeter.

(Received Feb. 9, 1996)

(Accepted for publication July 12, 1996)

目的 織機の性能向上之機能拡大を図るため; 各種の自動化装置が装着されるようになってきた。

このうち, ょこ入れ関連の装置においては, よこ系の挙動を詳細に把握する必要から, 小型, 高精度かつ高応答な非接触系速 度計の開発が望まれている。

非接触速度計測方法には，ドップラー効果を利用した方法，空間フィルタ法および光相関法などいくつかの方法があるが，な 汃でも，光相関法は柔软に装置を構成でき，上記要求を満足する系速度計に䔔した方法であると考えられる.

本研究では，高性能な系速度計を開発し，織機の性能向上に寄与することを目的としており，本報では，紡績系ならびにフィ

ラメント系を対象に，その透過光強度を調べるとともに，速度計を試作し，構成諸因子が湘定精度に及に゙す影響を調查した。

成果 紡績系およびフィラメント系を一定速度で移動させ, 透過光強度信号の周波数分析を行った結果, 糸種および移動速度 に沁じて振幅スペクトルに違いがみられた。 しかし，いずれの糸においてもスペクトルには, 卓越したピークは認められず, 信 号はほぼランダム信号と見なすことができ, 光相関法を適用するのに好適であることがかかった.

また, 試作速度計のスリット間距離やサンプリング間隔などを道切に設定した後, エアジェットルームのよこ入れ装置を静止 台上に設置した試験機を用いて,メインノズル入口部近傍の糸喷射過程におけるよこ系速度を計測した結果, レーザードップラ 一速度計とほぼ同等の精度で速度計测が可能であった。 


\section{1. 緒 言}

エアジェットルーム（AJL）をはじめとする織機 のよこ入れ性能の向上を図るため，糸の移動速度を 高精度に測定したいという要求がある. 測定におい ては, 系の挙動を乱さないという観点から, 非接触 計测が望ましく，これまでにも光学的手段を用いた 幾つかの報告例がある

このうち,レーザードップラー速度計 (LDV) を 用いた方法は，測定精度および応答性の面で優れて いる反面，レーザービームの交差点と糸の移動路を 一致させる必要から, 系の進路や光軸の調整が面倒 である.これに加え, 装置が大型であるため, 主に 実験室での利用に限られるなどの問題がある.

LDV 以外の非接触速度計としては, 光相関方式 の速度計（光相関速度計）や空間フィルター方式の 速度計が知られているが，これらの方式を系速度計 剆に適用した詳細な研究例は, 著者の知る限りな い.

上記速度計のうち, 光相関速度計は, 簡単なせン サー構成で信号計測が行えることから，小型化が容 易であり, 取り付け, 調整が簡単な系速度計として 有望と思われる。

本研究では，高性能な系速度計を開発し，織機の 性能向上に寄与することを目的としており，本報で は，系の光学特性ならびに速度計の構成諸因子が測 定精度に及ぼす影響について調べた結果を述べる.

また, AJLのよこ入れ装置を静止台上に設置した 試験機を用い, よこ入れ時の糸速度を試作速度計と LDV で同時計測した結果についてあ報告する。

\section{2. 主な記号}

本報で用いる主な記号を以下に示す.

$L: 2$ つのセンサー間の距離 $\mathrm{m}$

$t_{c}$ : 信号波形の相対位置をずらす区間 $\mathrm{s}$

$t_{s}:$ 基本デー夕計測区間 $\mathrm{s}$

$V_{c}$ : 試作速度計で求めた演算系速度 $\mathrm{m} / \mathrm{s}$

$V_{c e}:$ 譟差を含んだ演算系速度 $\mathrm{m} / \mathrm{s}$

$V_{L}:$ LDV で計測した糸速度 $\mathrm{m} / \mathrm{s}$

$V_{\mathrm{y}}:$ 実際の糸速度 $\mathrm{m} / \mathrm{s}$

$\Delta t: 2$ つの信号波形のずれ時間 $\mathrm{s}$

$\Delta V:$ 速度譔差 $V_{y}-V_{a} \mathrm{~m} / \mathrm{s}$

\section{3. 信号波形について}

光相関法を用いた速度計湘では，図 1 に示すよう

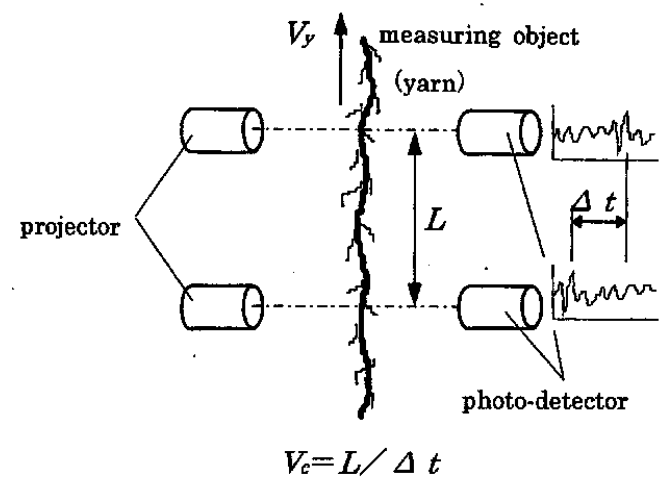

Fig. 1 Principle of optical correlation method.

に一定距離 $L$ を隔てて湘定対象に光を照射し， 2 か 所で計測した透過光強度または反射光強度の波形の ずれ時間 $\Delta t$ と $L$ から測定対象の移動速度を求め る.

従って, 測定精度は, その波形の特性（特徽の状 態）に依存し，光相関速度形を系速度計測に適用す るに当たっては，測定対象である系の光学特性を十 分に把握しておく必要がある.

糸には太さ，色，原料および製造方法の組み合わ せで多数の種類がある. そこで, 今回は代表的な系 種として, 紡績系（ポリエステルー綿混紡系 Ne45 (13.Itex), 綿糸 Ne15(39.4tex) およびフィラメン ト糸 (アセテート120D(13.3tex)-32F) を対象に, 図 9 に示す装置により，系を一定速度で移動させ, その透過光強度を調べた。なお，测定に際しては， 図 4 に示す光学系と, 図 5 に示す試作速度計の信号 処理回路の一部を用いた。使用したセンサーおよび 前段增愊器は，その周波数特性が測定結果に影響を 与えないように構成した。なお，上記装置および回 路等については後述する.

図 2 に測定結果の一例を示す. 図 2 には, 図 5 中 $\mathrm{a}$ 点の出力信号 $a_{\mathrm{sig}}$ をいったんコンピュータで保存 し, 投影直径に換算した後, 平均直径信号 $d_{\text {sig }}$ で正 規化したすのを表示した。

信号の変動振幅は, 紡績系がいずれも平均直径の 40\%程度であるのに対して，フィラメント糸は70\% 程度と大きくなっており，糸による違いが見られ る.

一方, 信号の変動周期は, いずれの糸においても, 移動速度が $5 \mathrm{~m} / \mathrm{s}$ 時より， $30 \mathrm{~m} / \mathrm{s}$ 時の方が全般的に 短くなっている. また, 同一移動速度においては, フィラメント糸は紡績系に比べ周期の長い変動が目 

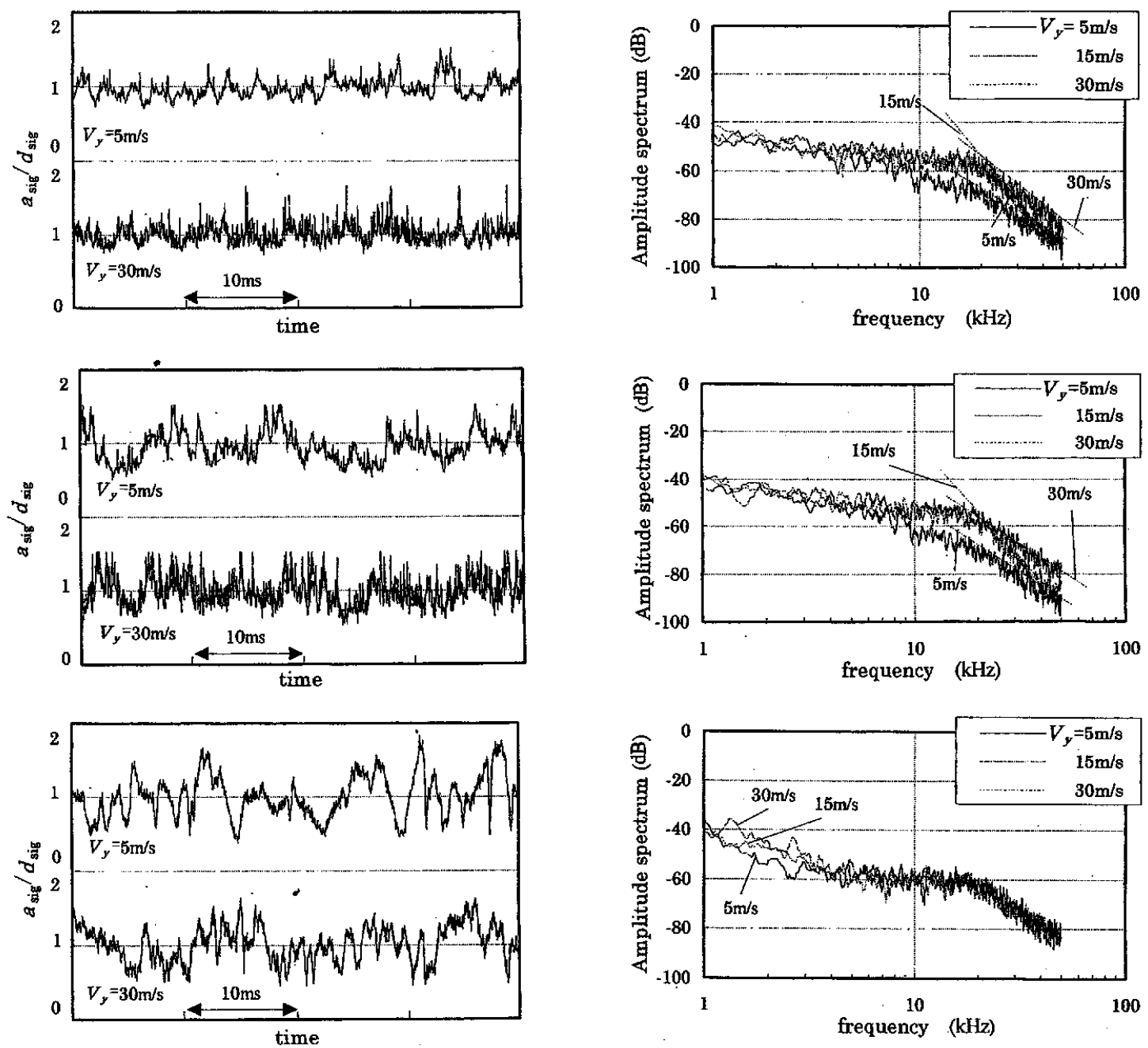

Fig. 2 Wave-form observations.
(a) spun (Ne45 (13.1 tex))
(b) spun (Nel5 (39. 4tex))
(c) filament (120D (13. 3tex) /32F)

立っている。

図 3 は, 図 2 の信号の振幅スペクトルを示した結 果であるが，いずれの系においてる，スペクトル中 に卓越したピークはなく，周波数が高くなるに従っ て，レベルが低下する傾向がある．また，紡績系に ついては移動速度が高くなるに従って, $10 \sim 50 \mathrm{kHz}$ のスペクトルが高周波数域にシフトし，フィラメン ト糸においては, $5 \mathrm{kHz}$ 以下のスペクトルに同様の 変化が認められる.

上記のようにいずれの系においても，スペクトル 中に卓越したピークがないことから，信号はランダ ム信号と見なすことができ，相関法を用いて速度計

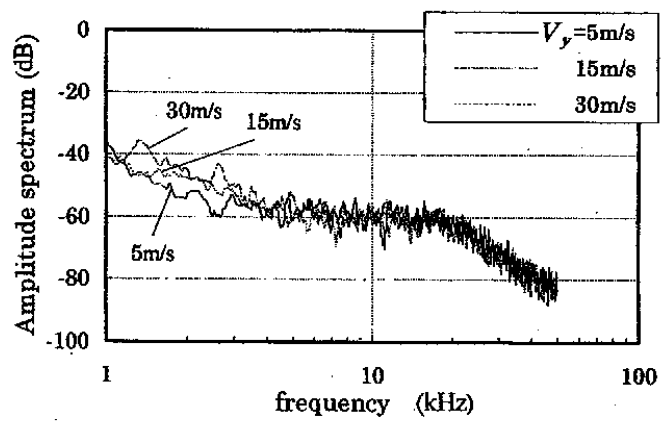

Fig. 3 Examples of an amplitude spectrum.
(a) spun (Ne45 (13. 1 tex))
(b) spun (Ne15 (39. 4tex))
(c) filament (120D (13. 3tex) /32F)

測を行うのに好適な信号であることがわかった．ま た,フィラメント糸は, 信号の変動周期が長いこと から，信号中の特徵の数を紡續系と同程度とするに は，信号計測区間を長くする必要があることもわか った.

上記の信号変動は, 紡績糸の場合主に太さむらや 表面の毛羽によって生じ, フィラメント系の場合 は，主に糸の姿勢変化や糸の長手方向に打ける緘維 の重なり具合の変化により生じると思われる，以下 に, Ne45(13.1tex) を例に紡績系の信号変動と毛羽 の関係について考察する.

表 1 は, 毛羽测定器（敷島紡績(㑣，F－INDEX 
Table 1 Examples of measured fluff.

\begin{tabular}{c|c|c}
\hline \hline $\begin{array}{c}\text { fluff head } \\
\text { (mm) }\end{array}$ & $\begin{array}{c}\text { F.INDEX } \\
\text { average }\end{array}$ & $\begin{array}{c}\text { F.INDEX } \\
\text { standard deviation }\end{array}$ \\
\hline 2.0 & 392.2 & 19.2 \\
\hline 3.0 & 143.0 & 6.3 \\
\hline
\end{tabular}

TESTER）を用いて Ne45(13.1tex) の毛羽量を測 定した結果の一例であり，表に示す F-INDEX か ら平均毛羽長と平均本数を求めると, $1.1 \mathrm{~mm}$ と 1080本 $/ \mathrm{m}$ となった.

信号変動が毛羽によって生じているとすれば，移 動速度と毛羽本数の積が，その移動速度における信 号変動の主たる周波数成分になると考えられる．上 記測定結果を例にとれば，移動速度が $5 \mathrm{~m} / \mathrm{s}$ の場合 においては, $1080 \times 5=5.4 \mathrm{kHz}$ が変動の主たる周波 数成分となり， $15 \mathrm{~m} / \mathrm{s}$ および $30 \mathrm{~m} / \mathrm{s}$ では， $16.2 \mathrm{kHz}$ と $32.4 \mathrm{kHz}$ となる．図3(a)の結果においては，スぺ クトル中に卓越したピークは見られないが，毛羽か ら予測した周波数域と, 移動速度が高くなるに従っ てスペクトルがシフトした周波数域とがほぼ対応し ていることから，信号変動と毛羽の間には有意な関 係があるものと思われる.

\section{4. 試作糸速度計の構成}

\section{1 検出部}

試作速度計は，検出部と信号処理部とからなり， 検出部は図 4 に示すように投光器と受光器を対向配 置した構造となっている. 投光器と受光器の間隔 は, 移動中の糸の蛇行を考慮し, 系が検出部に接触 しない最小間隔である $3 \mathrm{~mm}$ とした。

投光器は, 発光ダイオードとレンズ系からなって おり，連続光を系の移動方向と直角に交差するよう に照射する. 受光器は受光素子とその前面部にスリ ッドを設置した構成とした。なお，スリットの幅お よび高さは，測定信号に影響を及ぼす。

スリット幅を広くするに従って, 受光器の高周波 数域の検出感度が低下し, 速度計測に必要な信号成 分が失われる。一方, 幅を狭くしていくと一定の照 射光量の下では受光量自体が少なくなり, $\mathrm{S} / \mathrm{N}$ 比が 低下する，そこで，種々のスリット幅についてその 信号を測定し, 検出感度と $\mathrm{S} / \mathrm{N}$ 比のバランスを考 慮した結果, 幅 $0.5 \mathrm{~mm}$ が良好であった。

一方，スリット高さに関しては，寸法が小さくな るほど $\mathrm{S} / \mathrm{N}$ 比は増加するが, 計測空間が狭くなる.

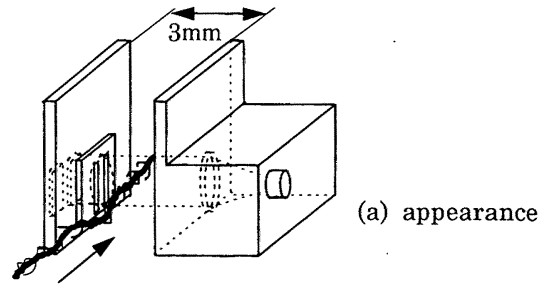

photo-diode SPD570 light-emitting diode TLN101

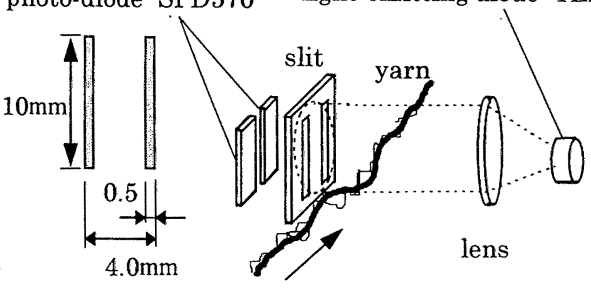

$\begin{array}{ll}\text { slit form } & \text { (b) structure }\end{array}$

Fig. 4 Construction of optics.

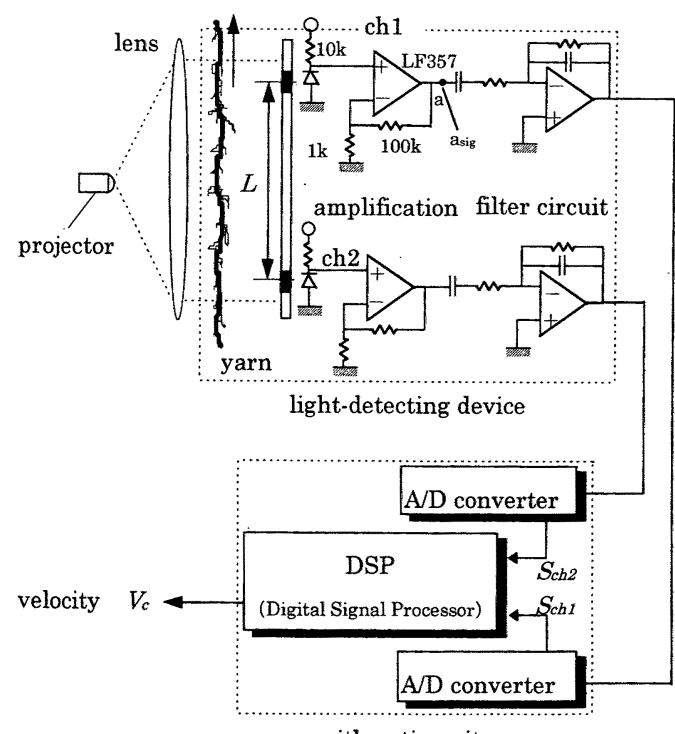

arithmetic unit

Fig. 5 Block diagram of developed speedometer.

試作速度計では, $\mathrm{S} / \mathrm{N}$ 比と取り付けの容易さを考慮 し，高さを $10 \mathrm{~mm}$ とした。なお，スリット間距離 $L$ については後述する.

\section{2 信号処理部}

信号処理部の構成を図 5 に示す. 信号処理部は, 受光素子の出力を増幅およびフィルター処理するア ナログ回路部之速度演算部とからなっている.

外乱光などによる不要な周波数成分の信号を除去 し, 速度計測に必要な信号のみを取得する目的か 


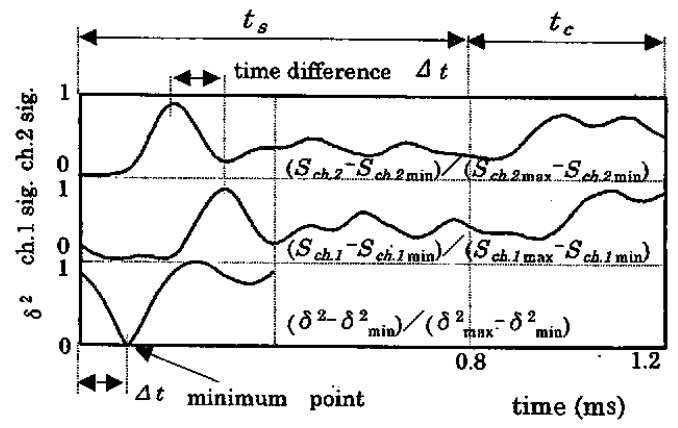

Fig. 6 An example of mean square error.

ら,フィルターにはバンドパスフィルター（通過帯 域0.16〜160kHz) を設けた.なお，フィルターの特 性は，前項の糸の透過光強度信号の周波数分析結果 を基に，速度計測に必要な信号が久落しないように 考虑しておる。

速度演算部は, A / D 変換器とDSP (Digital Signal Processor) により構成している.

図6にDSPに記憶した信号波形の一例を示す。 速度演算では，図のように信号を一定時間 $\left(t_{\mathrm{s}}+t_{c}\right)$ の空で切り取り，切り取った範囲においてDSPに より, ch. 1 信号 $\left(S_{c h .1}\right)$ と ch. 2 信号 $\left(S_{c h .2}\right)$ との ずれ量 $(\Delta t)$ を求め, $\left(t_{s}+t_{c}\right)$ 間の平均速度 $V_{c}$ を $V_{c}$ $=L / \Delta t$ の関係から算出する.

なお， $\Delta t$ は，(1)式に示す平均二乗誤差 $\delta_{2}$ を用い て求めた. $\delta^{2}$ を用いた場合， $\Delta t$ は誤差值が最小とな るサンプリング点のずれ量に対応し，求めたずれ量 に $\mathrm{A} / \mathrm{D}$ 变換器のサンプリング間隔 $\Delta t_{A D}\left(=1 / f_{\mathrm{s}}\right)$ を 乗じたものが時間差 $\Delta t$ となる.

$$
\delta_{12}^{2}\left(t_{c}\right)=\frac{1}{t_{s}} \sum_{t=0}^{t_{s}}\left(S_{c k 1}(t)-S_{c h 2}\left(t+t_{c}\right)\right)^{2}
$$

\section{3 測定精度の試算}

速度計を図 5 に示すように構成した場合，スリッ ト間距離 $L$ およびサンプリング周波数 $f_{s}$ が測定精 度に影響を与える。そこで，これらの因子の影響を 以下に示す指標を用いて調べた。

演算速度 $V_{c}$ は，(1)式により求めた $\Delta t$ を用いて算 出する. $\Delta t$ を求める際の精度は, $\Delta t_{A D}$ および DSP の演算精度に依存する. 一方, 実際の糸速度 $V, に お ~$ けるずれ量 $\Delta t_{y}$ は， $\Delta t_{y}=L / V_{y}$ で与えられる，

ここで, $\Delta t$ に含まれる誤差量を $\varepsilon$ とすれば，誤差 を含んだ演算速度 $V_{c a}$ は， $\Delta t_{y}$ と $V_{y}$ を用いて(2)式の ように表すことができる.

$$
V_{c \varepsilon}=\frac{L}{\Delta t}=\frac{L}{\left(\Delta t_{y}+\varepsilon\right)}=\frac{V_{y}}{\left(1+\frac{\varepsilon}{\Delta t_{y}}\right)}
$$

ここで， $V_{y}$ と速度誤差 $\Delta V=V_{y}-V_{c e}$ の比を演算 誤差率 $\alpha$ と定義し，さらに， $\varepsilon$ が $\Delta t_{A D}$ に比例して増 大するとみなし, $\varepsilon=\Delta t_{A D}$ を代入して, 1 サンプリン グ時間間隔に対応する $\alpha$ を求めると(3)式のように なる。

$$
\alpha=\frac{\left(V_{y}-V_{c \varepsilon}\right)}{V_{y}}=1-\frac{L}{\left(L+\frac{V_{y}}{f_{s}}\right)}
$$

(3)式によれば， $V_{y}$ が高くなるほど $\alpha$ は大きくな り，また， $f_{s}$ が高くなるほど $\alpha$ は小さくなる.さら に, $V_{y}$ と $f_{s}$ の影響は， $L$ の大きさにより異なること がわかる.

$f_{s}$ を一定として, $L$ および $V_{y}$ を変更した場合の $\alpha$ の計算結果を図 7 に示す。試作速度計の目標精度を $3 \%$ 以下と設定し，さらに，織機における $V_{y}$ の最高 值が $70 \mathrm{~m} / \mathrm{s}$ 程度であることを考虑すると $L$ を $4 \mathrm{~mm}$ 以上にする必要がある.

次に， $L$ を $4 \mathrm{~mm}$ として， $f_{s}$ および $V_{y}$ を変更した 場合の $\alpha$ の計算結果を図 8 に示す. $V_{y}=70 \mathrm{~m} / \mathrm{s}$ に おいて， $\alpha$ を $3 \%$ 以下にするためには， $f_{s}$ を $500 \mathrm{kHz}$ 以上にする必要がある.

以上の結果を基に, 試作速度計における $L$ および $f_{s}$ の標準値をそれぞれ $L=4 \mathrm{~mm}$ と $f_{s}=500 \mathrm{kHz}$ とし た.

\section{5. 測定精度}

\section{1 非直綜性誤差}

糸を図 9 に示す装置を用いて，一定速度で移動さ せ， $V_{c}$ の非直線性言差 $\gamma\left(\left(V_{y}-V_{c}\right) / V_{\text {ymax }}\right)$ を調べ た. 測定糸には Ne45 (13.1tex) を用い, $40 \mathrm{~m} / \mathrm{s}$ （=

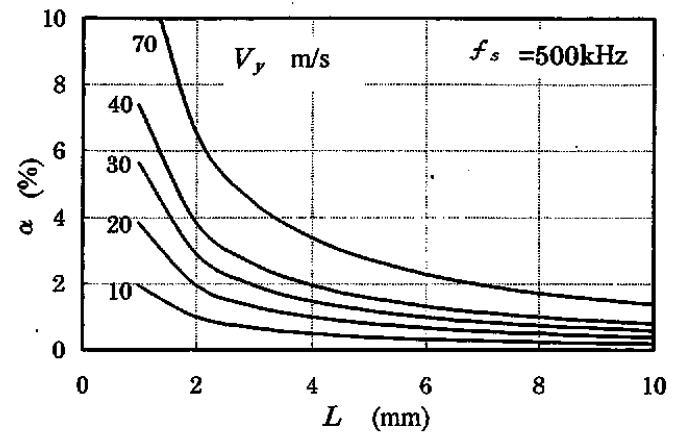

Fig. 7 Relationship between $\alpha$ and $L$. 


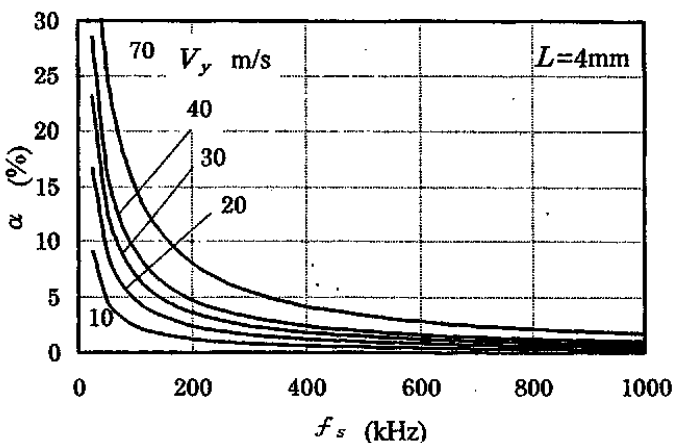

Fig. 8 Relationship between $\alpha$ and $f_{s}$.

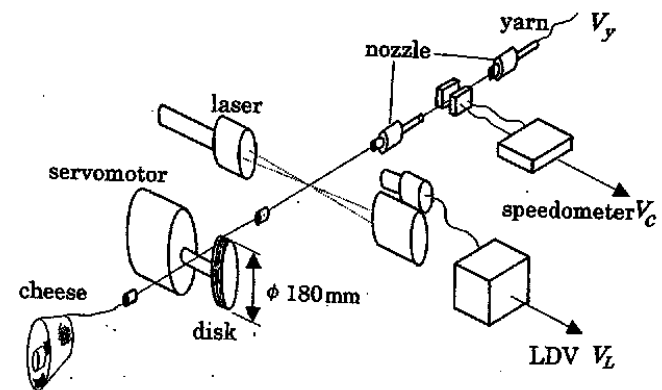

Fig. 9 Structure of test apparatus.

$V_{\text {max }}$ ）までの速度範囲で試験を行った，系の移動は， 系を多重に巻き付けた円盤をモーターで等速回転さ せることにより行い，円盤の回転数を反射型の光学 センサーを用いて計数することにより移動速度を求 めた，上記装置は，回転数が高くなり系に作用する 遠心力が増大すると，系と円盤の摩擦力が低下する ため, 移動速度と周速度に差が生じる。このため, 試作速度計に近接して LDV を設置し, 移動速度を 確認した。

$\gamma$ を調べるに当たって, $t_{s}, L$ および $f_{s}$ の测定精度 への影響について調查した。

相関法では，信号波形の計測区間 $t_{s}$.を長くし，信 号中に含まれる特徵の数を増加させるほど, 測定精 度が向上することが知られている，しかし、索を長 くすると逆に, 速度計の応答性が低下するため, 測 定精度と応答性のバランスをとる必要がある。一 方, $t_{s}$ の湘定精度への影響は; 測定される信号の特 性によって異なり，予測することは難しい。このた め, $t_{s}$ の影響を $V_{c}$ の標準偏差 $\sigma$ (測定数 100）と $V_{y}$ の比からなる指標 $\beta\left(=\sigma / V_{y}\right)$ を用いて調べた.

図10に結果の一例を示す. 図に示すように $t_{s}$ が長 くなるに従って，いずれの糸速度であ $\beta$ は小さくな

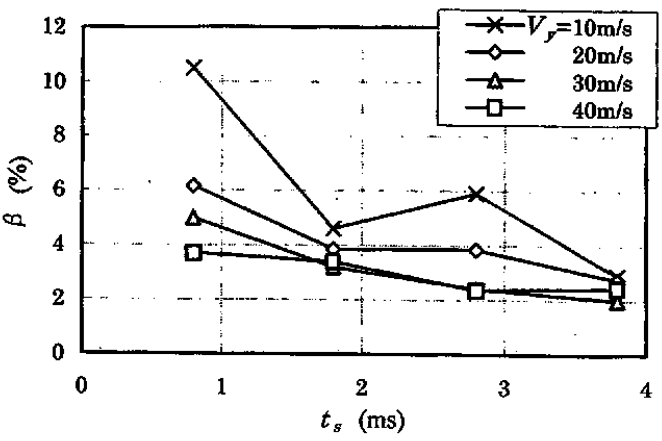

Fig. 10 Relationship between $\beta$ and $t_{s}$

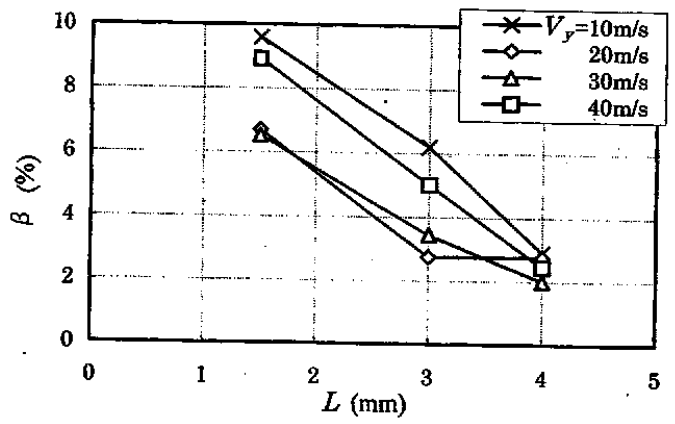

Fig. 11 Relationship between $\beta$ and $L$.

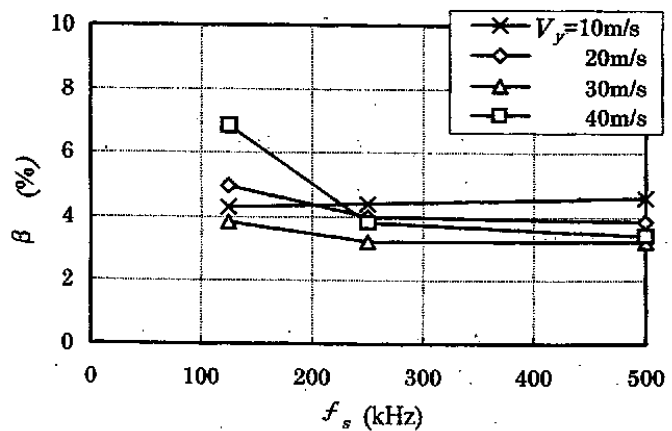

Fig. 12 Relationship between $\beta$ and $f_{s}$.

っている．例えば，AJL の製織中のよこ糸速度を剆 定し，系噴射過程の速度变化を精度良く求めるに は, 少なくとも噴射期間30〜 40ms の間に 20〜30 点 の测定を行う必要があり，このためには $t_{s}$ を $2 \mathrm{~ms}$ 以下にする必要がある，この場合， $\beta$ は 4\%以上と なる。

一方， $t_{s}$ 以外にも前述のようにLおよび $f_{s}$ が測定 精度へ影響する. $t_{\mathrm{s}}=1.8 \mathrm{~ms}$ として， $L$ および $f_{\mathrm{s}}$ の 影響を調べた結果を図11，図12に示す。

図11に示すように $L$ が增すに従って $\beta$ は小さく 


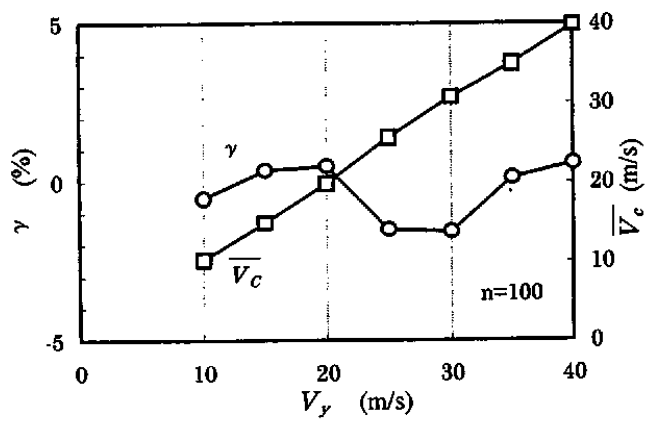

Fig. 13 An example of measured $\gamma$.

なり, 誤差が減少する傾向があり, 図 7 の計算結果 と同様の傾向が認められる. しかし, 速度の影響に 関しては㑯向が一致しなかった。

一方， $f_{s}$ の影響に関しては, 図12に示すように全 体的には $f_{\mathrm{s}}$ を高くするほど $\beta$ が小さくなり, 誤差は 減少する傾向にあり, 前述の図 8 と同様の傾向がみ られる.

これまでの結果を基に, $t_{\mathrm{s}}=1.8 \mathrm{~ms}, L=4 \mathrm{~mm}, f_{s}$ $=500 \mathrm{kHz}$ として, $\gamma$ を調べた結果の一例を図 13 に 示す. 図中には, $\gamma$ と $V_{c}$ の平均値 $\bar{V}_{c}$ を示した.この 例においては, $\gamma$ は最大 $2 \%$ 程度であった。

\section{2 よこ入れ速度の測定例}

試作速度計の測定条件を前述のように設定し，糸 噴射過程のよこ糸供給速度を測定した. 測定は, AJLのよこ入れ装置を静止台上に設置した試験機 (回転数500rpm) で行った. また, 尉定系には, Ne 45 (13.1tex) を用い, 試作速度計と LDV の同時計 測を行った，測定結果の一例を図14に示す.

図に示すように試作速度計の测定値は, LDV で 測定した速度波形とほぼ重なり，奏用上十分な精度 で測定が行えている.

なお， $t_{\mathrm{s}}=0.8 \mathrm{~ms}$ における結果す合わせて示した が, $1.8 \mathrm{~ms}$ の場合に比べ測定值の変動が大きく, LDV で測定した速度波形に対して, 若干高めの值 となっている.

\section{6. 結 言}

光相関法を系速度計測に適用するにあたって，糸 の光学特性を明確にするため, 一例として, 紡績系 およびフィラメント系の透過光強度を測定し，その 周波数特性の特徵を調べた。 また，速度計の構成諸 因子が測定精度に及ぼす影響を調查した。

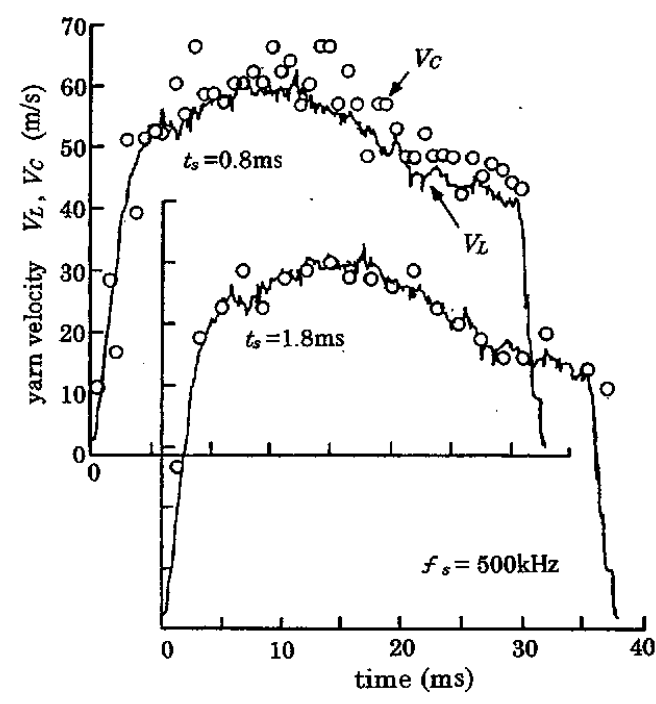

Fig. 14 Measured yarn velocity near the main nozzle.

さらに, AJLのよこ入れ装置を静止台上に配置し た試験機を用い，系噴射過程のよこ系速度をLDV と同時計測するなど試験を行い，以下の結果を得 た.

（1）フィラメント糸の透過光強度信号は，紡續系に 比べ周期の長い変動が目立った. 信号を周波数分 析した結果，いずれの糸においてす，振幅スペク トル中に卓越したピークはなく，相関法を用いる のに好適な信号であることがわかった。

(2) Ne45 (13.1tex) を対象に, 毛羽と信号変動の 関係を調べた結果，両者の間に有意な関係が認め られた。

(3) 速度計の構成因子を $L=4 \mathrm{~mm}, f_{\mathrm{s}}=500 \mathrm{kHz}, t_{\mathrm{s}}$ $=1.8 \mathrm{~ms}$ とした場合, 糸速度 $40 \mathrm{~m} / \mathrm{s}$ 以下での非 直線性譔差は $2 \%$ 以下であった。

（4）上記条件において，メインノズル入口部近傍の 系速度を計測した結果, 試作速度計の測定値は, LDV で測定した速度波形上にほぼ重なり，寒用 上十分な精度が得られることがわかった。

\section{謝 辞}

本研究を進めるに当たり，偢豊田自動織機製作所 織機技術部の関係者の皆様に協力を頂き，感謝いた します。

\section{参考文献}

1）山口一郎；“スペックル応用計測の最近の進歩”, 精密工学 
会誌, 57 (1991) 1948－194.

2) M. H. Butterfield, G. F. Bryant and J. Dowsing ; A New Method of Stripspeed Measurement Using RondomWaveform Correlation, Trans. S. I. T, 13, 111/123 (1961)

3）磯部編；“相関関数およびスベックル", 東京大学出版会 (1968)

4) 䑤島紡結(1)，“光学式毛羽カウンター取り报い説明書”

5）吉田, 他：“エアシェットルームにおけるよこ糸の速度変
動”, 䋐機誌, 44, No. 2 (1991)

6) G. Hoth und M. von Thenen ; "Rechnergesteuerte MeBwertaufnahme mehrerer schnel ablaufender Messgrössen", Textilpraxisinternational, Juli, (1983), p650653

7) G. C. Dubbeldam ; "The Contactless Measurement of Yarn Speed with a Layser-Doppler Velocity Meter", J. of Textile Institute, 65, (1974-9), p483-487 